\title{
New English Teaching Mode in Colleges
}

\author{
http://dx.doi.org/10.3991/ijet.v9i3.3202 \\ Yanmei Song \\ Nan Yang Institute of Technology, Nan Yang, China
}

\begin{abstract}
In recent years, increasing use of the Internet has changed English teaching methods. In this study, we constitute and propagate one new English teaching mode in colleges. It is three-dimensional which comprises online class, regular class and extracurricular activities. Its three prominent feathers include highlighting the students' important position; highlighting English comprehensive application and autonomous learning ability and extending computer network autonomous learning. Furthermore, five general implementing processes are included. Through feedback questionnaire and average marks comparison, we found that this mode improved the efficiency of experiment classes. It is hoped that this new mode would be able to assist more teachers to improve their teaching efficiency and more English learners to improve their learning efficiency.
\end{abstract}

Index Terms-Contents and Feathers, Implementation processes, Effect

\section{INTRODUCTION}

It is no doubt that the traditional teaching mode which used chalk, blackboard and textbook to teach language knowledge and skills played an indispensable role in china English-teaching history. However, most of the students' language communicative ability was poor, and "deaf English" and "dumb English" phenomena were quite common. Along with the further opening up to the outside world and the rapid development of social economy, it's urgent to improve college students' English level, especially listening and speaking ability.

\section{CONTENTS AND FEATURES}

In this situation, the new mode which is called the webbased college English teaching mode came into being with the author's efforts and experiments. It is presented in Fig.1. It includes five parts, namely, teaching object, teaching content, teaching environment, teaching methods and teaching organizers. The students who are the center of learning, improve their comprehensive application ability in a series of activities such as listening, speaking, reading, writing and translating, especially listening and speaking ability through online class, conventional class and extracurricular activities. This web-based college English teaching mode is three-dimensional which comprises online class, regular class and extracurricular activities. It has the following feathers: highlighting the students as the center and the prominent position in study; highlighting the combination of language knowledge imparting, English comprehensive application ability and autonomous learning ability training in the teaching contents; extending teaching methods from traditional classroom teaching to computer network autonomous learning complementary along with the second classroom activities.

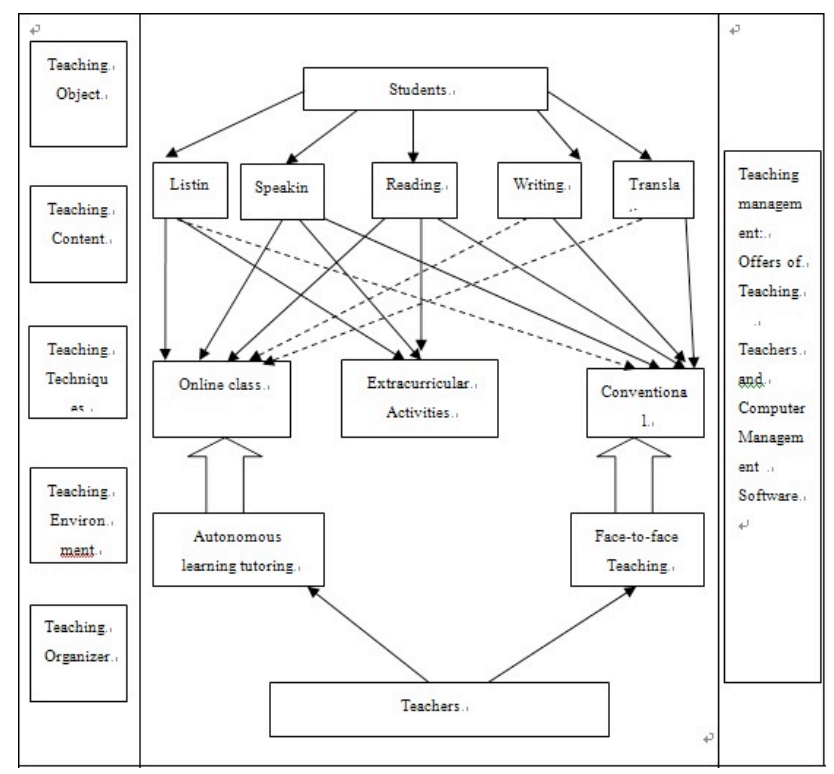

Figure 1. The web-based college English teaching mode

Therefore, the new teaching mode makes full use of modern information technology, breaks the time and place limit for the students' foreign language learning and provides students with a good language learning environment. So we can say that this is a kind of new mode which has several different features.

\section{THE IMPLEMENTATION PROCESSES}

The new mode emphasizes the design of the mutual activities. Students learn autonomously in the online class first and then they present what they have learned in the regular class. As a result, the object of communication is realized in students-students and teachers-students dynamic communication. The teaching implementation process is presented as follows:

Firstly, teachers upload the teaching goal through the task sample to online class "notice" column for students to download.

Secondly, the students complete input tasks independently (such as background reading, language knowledge, information retrieval and language skills training, etc.) through the network classroom "resource" module and design their respective tasks according to the sample design.

Thirdly, students do partner activities and group discussion in conventional class and the second class activities.

Fourthly, students make personal representative theme speech or collective display, or take part in other activities after discussion. 
Lastly, teachers summarize and evaluate the conventional class process in this period and assign next new task.

From the above, we can see that the whole teaching process is the process of the student active construction, constantly taking part in activities and actively discussing. In this process, there are student-computer communications on the students' self output stage and the studentsstudents communication on output stage. Also, there is the language input in online class and the language output in the classroom and the second class activities. Teachers only set task framework and the tasks are designed and finished completely by the students themselves which not only mobilize and inspire the students' interest but also train their ability to learn. Of course, "teachers should be teaching controller, director, manager, promoters and information providers in interactive teaching".

\section{RESULTS AND DISCUSSION}

In order to coordinate the implementation of the project, the author issued "college English teaching mode feedback questionnaire" to 333 students in experimental classed and got 306 effective questionnaires.

The specific situation is shown in table 1. From Table 1 , we believe that the vast majority of students affirm and accept the new teaching mode and only a small part of students is not adapt to this new teaching mode.

In order to understand and master more about this webbased teaching mode, the author held a face-to-face informal discussion, asking their opinions and suggestions to the new teaching mode. About $80 \%$ of the students said that the new English teaching mode is quite good and 20\% of the students put forward that the mode itself is good but it needs more time for them to adapt it.

Another major index is the student achievement, which is composed of two aspects: integrated course and listening and speaking class. The author compared the marks in the final examination between 333 students in experiment class and 355 students drawn randomly from the non experiment class. The results are presented in tables II, III and IV.

From the numbers in tables 2, 3 and 4, it can be seen clearly that the overall average marks in integrated items, listening items and speaking item in experimental classes are higher than those in non experimental classes. The good results in listening and speaking are more obvious. So we can draw the conclusion that the new teaching mode is effective and useful to college students in Nan Yang Institute of Technology.

TABLE I.

COLLEGE ENGLISH TEACHING MODE FEEDBACK QUESTIONNAIRE

\begin{tabular}{lcccccc}
\hline \multicolumn{1}{c}{ Items } & $\begin{array}{c}\text { Very } \\
\text { good }\end{array}$ & Better & General & Bad & Poor \\
\hline Integrated course & 147 & 104 & 37 & 18 & 0 \\
Listening and speaking course & 159 & 80 & 46 & 21 & 0 \\
Autonomous learning course & 183 & 84 & 39 & 0 & 0 \\
The whole teaching result & 194 & 51 & 25 & 36 & 0
\end{tabular}

\section{REFERENCES}

[1] Brown, D., 2001. Teaching by Principles: An Interactive Approach to Language Pedagogy. Foreign language teaching and research press, Beijing, China, PP160

[2] Littlewood, W.,1999(1). Defining and Developing Autonomy in East Asian Contexts. Applied Linguistics, pp71-94 http://dx.doi.org/10.1093/applin/20.1.71

[3] Ministry of Education, 2007. College English Curriculum Requirements. Shanghai foreign language education press, Shanghai, China, PP1-2

\section{AuTHORS}

Yanmei Song is with Foreign Language College, Nan Yang Institute of Technology, Henan, China (e-mail: songyanmei73@sina.com)

Manuscript received 09 March 2013. Published as re-submitted yby the author 18 May 2014.

TABLE II.

COMPARATIVE INTEGRATED ITEMS AVERAGE MARKS BETWEEN EXPERIMENTAL CLASS AND NO EXPERIMENTAL CLASS FINAL EXAM IN THE FIRST SEMESTER OF 2012-2013 SCHOOL YEAR

\begin{tabular}{|c|c|c|c|c|}
\hline $\begin{array}{ll}\text { class } & \text { Items } \\
\end{array}$ & $\begin{array}{l}\text { Vocabulary } \\
(15 \text { marks) }\end{array}$ & $\begin{array}{l}\text { Structure } \\
(15 \text { marks })\end{array}$ & $\begin{array}{c}\text { Reading Comprehension } \\
\text { (40 marks) }\end{array}$ & Overall average marks \\
\hline Experimental class & $337.30 / 333=10.142$ & $3270.16 / 333=9.82$ & $9550.83 / 333=28.681$ & $16198.284 / 333=48.643$ \\
\hline Non experimental class & $3597.57 / 355=10.134$ & $3602.19 / 355=10.147$ & $100019.88 / 355=28.225$ & $17219.99 / 355=48.507$ \\
\hline
\end{tabular}

TABLE III.

COMPARATIVE AVERAGE MARKS ABOUT LISTENING ITEMS BETWEEN EXPERIMENTAL CLASS AND NO EXPERIMENTAL CLASS FINAL EXAM IN THE FIRST SEMESTER OF 2012-2013 SCHOOL YEAR

\begin{tabular}{|c|c|c|c|c|c|}
\hline $\mathrm{C}_{\text {class }}$ Items & $\begin{array}{l}\text { Short conversa- } \\
\text { tions }(20)\end{array}$ & $\begin{array}{c}\text { Long Conversations } \\
(\mathbf{3 0})\end{array}$ & $\begin{array}{l}\text { Passages } \\
\text { (20) }\end{array}$ & $\begin{array}{l}\text { Compound Dicta- } \\
\text { tion (10) }\end{array}$ & Overall average marks \\
\hline Experimental class & $3834 / 333=11.51$ & $8812 / 333=26.46$ & $3640 / 333=10.93$ & $2664 / 333=8$ & $18950 / 333=56.91$ \\
\hline Non experimental class & $1982 / 189=10.49$ & $4780 / 189=25.29$ & $2232 / 189=11.81$ & $1492 / 189=7.89$ & $10486 / 189=55.48$ \\
\hline
\end{tabular}

TABLE IV.

COMPARATIVE AVERAGE MARKS ABOUT SPEAKING ITEMS BETWEEN EXPERIMENTAL CLASS AND NO EXPERIMENTAL CLASS FINAL EXAM IN THE FIRST SEMESTER OF 2012-2013 SCHOOL YEAR

\begin{tabular}{lccc}
\hline Items & Passages Reading (60) & Spoken English Expression (40) & Overall average marks \\
\hline Experimental class & $17435.88 / 333=52.36$ & $12031.29 / 333=36.13$ & $29467.17 / 333=88.49$ \\
Non experimental class & $16847.15 / 355=50.29$ & $11530.4 / 355=32.48$ & $28377.55 / 355=79.94$
\end{tabular}

